\title{
Assessment of Bactericidal and Phytochemical Properties of Adhatoda vasica Various Extracts against Gram Positive and Gram Negative Bacteria
}

\author{
Ekta Chaudhary, Renu Chauhan and Neha Chauhan*
}

Division of Life science, Shri Guru Ram Rai Institute of Technology and Science, Dehradun,

Uttarakhand, India

*Corresponding author

\section{A B S T R A C T}

Keywords

Adhathoda vasica, Antibacterial

activity,

Phytoconstituents,

Zone of inhibition.

Article Info

Accepted:

29 June 2017

Available Online:

10 July 2017
Bacterial resistance against traditional antibiotics has posed a major problem nowadays and the phytoconstituents present in medicinal plants has the potential to combat bacterial infections. Leaves of Adhathoda vasica plant were screened for its medicinal property. Antibacterial activity was analyzed by preparing its extracts in different solvents like ethyl acetate, methanol and Distilled water (in increasing polaritry). Results obtained were compared with commercial antibiotic Gentamicin (used as control) on gram positive and gram negative bacteria (S. aureus, E. coli, Pseudomonas, Bacillus, S. typhi). The results obtained showed effective results. Different extracts of leaves exhibited varied degree of inhibition against the selected microbes. The best result was observed in ethyl acetate extract (zone of inhibition against E. coli was $27 \mathrm{~mm}$ ). Phytochemical analysis also showed varied percentage of phytoconstituents responsible for the medicinal activity.

\section{Introduction}

From prehistoric time, plants are used for their medicinal property. Various parts of the plant are used for the preparation of medicines for various ailments. Plants make many chemical compounds to protect themselves against fungi, bacteria or mammals, this act in same way on human body as allopathic drugs. These compounds present are estimated around about 12,000. Plants use as drugs has undergone tremendous increase as pathogens are developing resistance against the frequent use of drugs. New drugs with better effect are needed to provide good health facility. Another benefit of these drugs are that they are safe and costeffective, a gift for the non-industrialized and underdeveloped countries. Another reason for the development of these drugs is population rise, prohibitive cost of treatments, sideeffects of other synthetic drugs. India is a large repository for herbal plants in world. About 8,000 herbals are codified in AYUSH systems in India. Worldwide, 80 percent of people rely on herbs, notified by WHO (world health organization). As per data three-quarter of population rely on plants and their extracts for health care (https://en.m.wikipedia.org> wiki $>$ medicinal plants). Commonly used 
herbs in every household are aloe, tulsi, neem, turmeric and ginger for care of common ailments. Major diseases are also treated by the herbal plants. AYURVEDA and UNANI works on these medicinal plants help to provide their benefit to people (https://nhp.gov.in introduction and importance of medical plants and herbs). The active ingredients present in plant are many but mainly used and important are Alkaloids bitter tasting chemicals. Glycosides - drug containing these are used to support the beating of the heart and act as diuretics; Polyphenols - drugs used to treat gynaecological problems; Terpenes - strongly aromatic and used by plant to repel het bivores.

Different herbs have different properties, used to care different aliments. Some are used to treat sores and boils while some have blood cleansing and antibiotic property. Fever and poisons cases are also cured. Astringent action, antacid property, cough care and many more action are served by the herbal plants. One of the herbal plants which are widely used is Adhatoda vasica nees used to care ailments like asthma, tuber-culosis, piles, jaundice and many more. Commonly known Malabar nut or adulsa come from Acanthaceae family native to Asia. The plant ranges in Sri Lanka, India, Bangladesh, Pakistan, Indonesia and Malaysia. Leaves, bark, roots, flower of Adhatoda are full of medicinal property. Various extract of plants are used to care pulmonary, bronchial and asthmatic disorders. It is also used to speed childbirth (kanthale et al., 2014). The adhatodha vasica leaves extract were screened for their Phytochemical content. Quantitative test were used to detect the presence of alkaloids, tannins, flavonoids, saponins, phenolic acid. Presence of these phytochemicals in the medicinal plants indicates the presence of antibacterial properties against S. aureus, E. coli, Pseudomonas aeruginosa, Bacillus subtilis and S. typhi. Aim of this study is to identify various medicinal properties of Adhatodha vasica plant. Leaf was the main part of the plant used for the observation of medicinal properties. Phytochemical analysis was also conducted and presence of these botanicals was determined in order to support the medicinal efficacy of the plant.

\section{Materials and Methods}

\section{Plant material and extraction}

The dried mature leaves of Adhatodha vasica were collected from local area in Bhaniyawala Dehradun, India. Washed with distilled water and the leaves were separated and kept in a clean shaded place for 9-10 days, grounded to a powder and weight the whole powder. Cold Maceration method is used to prepare extracts. $250 \mathrm{ml}$ of organic solvents ethyl acetate, methanol and water is taken and $25 \mathrm{gm}$ of leaf and flower powder is soaked in it. Extracts obtained are made solvent free and concentrated by rotary evaporator and kept at $4{ }^{\circ} \mathrm{C}$ in airtight bottle until further use (akhter et al., 2014).

\section{Chemicals and Reagents}

Chemicals and reagents used are-for the study are- Ethyl acetate, Methanol, Conc. Ammonium hydroxide, 20\% Acetic acid, Folin- Ciocalteacee reagent, Sodium carbonate (20\%), Dil.

Folins-phenol reagent (1:1 ratio with water), Gallic acid, Sodium nitrate(5\%), Aluminum chloride(10\%), Sodium hydroxide(4\%), Polyvinyl polypyrrolidone, Vanillin reagent $(800 \mathrm{gm}$ of vanillin in $10 \mathrm{ml}$ of $99.5 \%$ ethanol), Sulphuric $\operatorname{acid}(72 \%), \quad 2,6-$ dichloroindophenol sodium salt hydrate, Metaphosphoric acid(1\%), L- Ascorbic acid and Distilled water. These reagent and chemical are used in a pure state (Table 1). 


\section{Microorganisms}

Five microorganisms representing Grampositive and Gram-negative bacteria were used. The two gram-positive bacteria wereStaphylococcus aureus and Bacillus subtilis and the three gram-negative bacteria wereEscherichia coli, Pseudomonas aeruginosa and Salmonella typhi.

\section{Antimicrobial activity}

\section{Agar well diffusion method}

Antibacterial activities of all the extracts (ethyl acetate, methanol, aqueous) of $A$. vasica were determined by agar well diffusion method (Chauhan, Neha et al., 2012). In this method DMSO (dimethylsulphoxide) was dissolved in the extract to obtain $0.5 \mathrm{mg} / 100 \mu \mathrm{l}$ and $1 \mathrm{mg} / 100 \mu \mathrm{l}$ concentrations. Commercial antibiotic (Gentamicin) and DMSO was taken as positive and negative control respectively. The test was done in triplicates and the final results obtained were presented as the mean zone of inhibition (Sawhney et al., 2011)

\section{Broth dilution MIC tests (NCCLS, 1993)}

This test was done to check the zone of inhibition which was minimum. This process in named as macro broth dilution assay. Muller- Hinton broth diluents was taken and 2-fold serial dilutions of all extract were prepared in the well on the basis of result obtained from agar well diffusion method.

Gentamicin and DMSO are positive and negative control respectively $20 \mu \mathrm{l}$ of test culture at concentration $\left(5 \times 10^{5} \mathrm{cfu} / \mathrm{ml}\right)$ which is standard was inoculated and plates were incubated for $24 \mathrm{~h}$ at $37^{\circ} \mathrm{C}$ plate with minimum growth was taken and concentration is noted as minimum inhibitory concentration. Another value minimum bacterial count was calculated by spreading $20 \mu \mathrm{l}$ of MIC test broth on a new plate incubating for $18-24 \mathrm{~h}$ at $37^{\circ} \mathrm{C}$. Dilution of plate showing no single bacterial growth was taken as MBC concentration.

Triplicates were used to perform test and mean MIC and MBC value were calculated and noted (Chauhan neha et al., 2012)

\section{Phytochemical analysis}

Phytochemical analysis was done in accordance to (Sharma et al., 2014).

\section{Test for glycosides}

Take $1 \mathrm{ml}$ of plant extract and add few drops of sulphuric acids and the mixture was allowed to stand for some time, formation of Reddish precipitate that means Presence of glycosides was confirmed.

\section{Test for carbohydrates (Molisch's test)}

Take $1 \mathrm{ml}$ of extract and add $2 \mathrm{ml}$ of Molisch's Reagent. Now to this mixture, $2 \mathrm{ml}$ conc. sulphuric acid was added along the sides of the test tube. Presence of carbohydrates was confirmed by formation of reddish violet ring.

\section{Test for flavonoids (Aqueous test)}

Take $1 \mathrm{ml}$ of plant extract, $1 \mathrm{ml}$ of aqueous $\mathrm{NaOH}$ was added. Presence of flavonoids was confirmed by yellow colour formation.

\section{Test for saponins (Aqueous test)}

Take $1 \mathrm{ml}$ of extract, $5 \mathrm{ml}$ water was added and shake well in test tube shaker. Presence of saponins was confirmed by Lather formation. 


\section{Test for tannins (Ferric chloride test)}

Take $1 \mathrm{ml}$ of plant extract, $1 \mathrm{ml}$ of ferric chloride was added. Presence of tannins was confirmed by the formation of greenish black colour.

\section{Test for alkaloids (Dragondroff's reagent)}

Take $1 \mathrm{ml}$ of plant extract add 5-6 drops of dragondroff's reagent. Presence of alkaloids was confirmed by the formation of creamish/ brownish-red/ orange precipitate.

\section{Quantitative and qualitative analysis} (Sharma et al., 2014)

Phytochemicals- Phenolics, Saponins, Flavonoids and Ascorbic acid Tannins and Alkaloids provide antibacterial properties to the medicinal plant against $S$. aureus, $S$. typhi, E. coli, Bacillus and Pseudomonas. Phenolics, Saponins, Flavonoids and Ascorbics were detected by Quantitative tests and Tannins and Alkaloids by Qualitative tests.

\section{Test for total phnolic content}

Sidduraju and Becker method was used to estimate total phnolic content of $A$. vasica by using folin ciocalteace reagent. $1 \mathrm{ml}$ solution of 20 microgram leaf extract were prepared with distilled water.

Then in this two reagents were added- $500 \mu 1$ diluted folins- phenol reagent (1:1ratio with water) and $2.5 \mathrm{ml}$ of $\mathrm{Na} 2 \mathrm{Co} 3$ (sodium carbonate) $20 \%$. Then it was shaken well and incubated for $40 \mathrm{~min}$. in dark condition, for the development of colour. After it, the absorbance was measured at $725 \mathrm{~nm}$. Gallic acid calibration curve was constructed and linearity was obtained in the range of 10-50 $\mu \mathrm{gm} / \mathrm{l}$. Then standard curve was used to obtain the total phenolic content in the plant extract which was expressed as mg. of Gallic acid equivalent (GAE/g extract).

\section{Test for total saponin content}

It was estimated by the method described by Makkarte et al., based on vallin-sulphuric acid colorimetric reaction with some

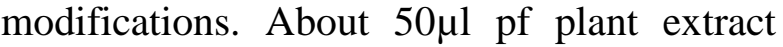
was added in $250 \mu 1$ of vanillin reagent (800mg of vanillin in $10 \mathrm{ml}$ of $99.5 \%$ ethanol) and was mixed.

Then $2.5 \mathrm{ml}$ of $72 \%$ sulphuric acid was added and it was mixed well. This solution was kept in a water bath at $60^{\circ} \mathrm{C}$ for $10 \mathrm{~min}$. after $10 \mathrm{~min}$. Ice cold water was used to cool it and the absorbance was measured at $544 \mathrm{~nm}$. The values obtained were expressed as diosgenin equivalent (mg DE/g extract) which was derived from a standard curve.

\section{Test for total flavonoids content}

The total flavonoids content was estimated using the procedure described by Zhishen $e t$ al., A total of $1 \mathrm{ml}$ of plant extract were diluted with $200 \mu \mathrm{l}$ of distilled water separately followed by the addition of $150 \mu 1$ of sodium nitrite $(5 \%)$ solution.

This mixture was incubated for $5 \mathrm{~min}$. and then $150 \mu \mathrm{l}$ of aluminium chloride (10\%) solution was added and allowed to stand for $6 \mathrm{~min}$. Then $2 \mathrm{ml}$ of sodium hydroxide (4\%) solution was added and made up to $5 \mathrm{ml}$ with distilled water.

The mixture was shaken well and left it for $15 \mathrm{~min}$ at room temp. The absorbance was measured at $510 \mathrm{~nm}$. Appearance of pink colour showed the presence of flavonoids content. The total flavonoids content was expressed as rutin equivalent $\mathrm{mgRE} / \mathrm{g}$ extract on a dry weight basis using the standard curve. 


\section{Results and Discussion}

\section{Antibacterial activity}

Various extracts of $A$. vasica leaves showed potent antimicrobial activity against the pathogens causing infections in humans. The E1 extract was found to be the most effective in suppressing the growth of selected pathogens as the values of ZOI were higher. S1 was the highest susceptible pathogen as the ZOI was $27 \mathrm{~mm}(1 \mathrm{mg} / 100 \mu \mathrm{l})$ and least susceptible was $\mathrm{S} 5$ as ZOI was $20 \mathrm{~mm}$ $(1 \mathrm{mg} / 100 \mu \mathrm{l}) . \mathrm{S} 5$ at $1 \mathrm{mg} / 100 \mu \mathrm{l}$ (ZOI values) showed maximum susceptibility against E2 extract and $\mathrm{S} 2$ at $1 \mathrm{mg} / 100 \mu 1$ (ZOI values) was least susceptible. E3 extract effectively inhibited S2 at $1 \mathrm{mg} / 100 \mu \mathrm{l}$ (ZOI values) and least inhibition was shown against S4 (ZOI values). The data obtained from antimicrobial activity of E1, E2 and E3 extract against pathogens were tabulated in tables 3, 4 and 5. The extracts that showed high efficacy against selected pathogens were subjected to minimum inhibitory concentration (MIC) assay by two-fold serial dilution method $(2: 2)$ $(9,10)$ (Table 2).

\section{Phytochemical analysis of Adhatodha vasica leaves extracts}

\section{Qualitative analysis}

Phytochemical analysis of Adhatodha vasica leaves in ethyl acetate extract exhibit the presence of Saponins, carbohydrates, flavonoids, tannins and alkaloids. Glycosides are absent in both the extracts. Methanolic extract also exhibit the presence of saponins, carbohydrates, falvonoids, tannins and alkaloids. Glycosides are absent in both the extracts. Aqueous extract exhibit the presence of saponins, carbohydrates, flavonoids, tannins and alkaloids. Glycosides are absent in both the extracts. Results are presented in table 6 (Fig. 2).

\section{Quantitative analysis}

Phytochemical assessment of A. vasica plant leaves extracts was done using quantitative methods. The E1 extract showed the presence of phenol, saponins and flavanoids upon investigation (Table 7). Flavonoid was found to be the highest $(0.106)$ followed by saponins (0.052) and phenol (0.023). The E2 extract possessed the highest amount of phenol (0.037) whereas saponins and flavonoids were found to be less in comparison (0.019). The E3 extract upon investigation revealed the presence of saponins (as 0.094) as highest followed by phenol (0.011) and flavonoids (0.009). These botanicals exhibit the potent inhibitory activity of leaves extracts against all the selected human pathogens.

\section{Antibacterial activity}

Adhatoda vasica leaves extract were used to study for antibacterial properties of plant. $S$. typhi showed least influence against the all three extracts (E1, E2 \& E3) of A. vasica.

E1 extract showed strong inhibitory activity against $E$. coli followed by bacillus, but moderately inhibit the growth of $S$. typhi and $S$. aureus and was least effective against Pseudomonas. Maximum ZOI for E2 extract was shown by $S$. typhi followed by $S$. aureus, E. coli, Pseudomonas and Bacillus.

E3 extract effectively inhibit the growth of Bacillus, S. aureus, Pseudomonas, E. coli and $S$. typhi. In the study by Ramachandra et al., 2013, done on antibacterial activity of extracts of $A$. vasica, methanolic extract was found to possess maximum antibacterial activity against $S$. aureus while in our study maximum inhibitory activity was recorded by E1 extract for E. coli (Tables 8-10 and Fig. $1)$. 
Table.1 The yield and physical properties of A. vasica

\begin{tabular}{|l|l|l|l|l|}
\hline S.no & Solvent used & Yield $\mathbf{( g / 2 5 0 m l )}$ & Colour & State \\
\hline 1. & Ethyl acetate E1 & 11.016 & Blackish green & Viscous \\
\hline 2. & Methanol E2 & 15.277 & Blackish green & Viscous \\
\hline 3. & Water E3 & 16.755 & Brownish & Solid \\
\hline
\end{tabular}

Table.2 Antibacterial activity of Gentamicin

\begin{tabular}{|l|l|l|l|}
\hline S.No & \multirow{2}{*}{ Microbial Culture } & Concentration of the E1 extract \\
\cline { 3 - 4 } & & $0.5 \mathrm{mg} / 100 \mu 1$ & $1 \mathrm{mg} / 100 \mu 1$ \\
\hline 1. & S1 & 31 & 35 \\
\hline 2. & S2 & 26 & 30 \\
\hline 3. & S3 & 27 & 32 \\
\hline 4. & S4 & 24 & 28 \\
\hline 5. & S5 & 22 & 27 \\
\hline
\end{tabular}

Table.3 Antibacterial activity of Adhatodha vasica E1 extract

\begin{tabular}{|l|l|l|l|}
\hline S.No & \multirow{2}{*}{ Microbial Culture } & Concentration of the E1 extract \\
\cline { 3 - 4 } & & $0.5 \mathrm{mg} / 100 \mu \mathrm{l}$ & $1 \mathrm{mg} / 100 \mu \mathrm{l}$ \\
\hline 1. & S1 & 24 & 27 \\
\hline 2. & S2 & 19 & 21 \\
\hline 3. & S3 & 21 & 25 \\
\hline 4. & S4 & 21 & 23 \\
\hline 5. & S5 & 14 & 20 \\
\hline
\end{tabular}

Table.4 Antibacterial activity of Adhatodha vasica E2 extract

\begin{tabular}{|l|l|c|c|}
\hline \multirow{2}{*}{ S.No } & \multirow{2}{*}{ Microbial Culture } & \multicolumn{2}{|c|}{ Concentration of the E2 extract } \\
\cline { 3 - 4 } & & $0.5 \mathrm{mg} / 100 \mu 1$ & $1 \mathrm{mg} / 100 \mu 1$ \\
\hline 1. & S1 & 13 & 15 \\
\hline 2. & S2 & 9 & 11 \\
\hline 3. & S3 & 10 & 13 \\
\hline 4. & S4 & 18 & 18 \\
\hline 5. & S5 & 15 & 17 \\
\hline
\end{tabular}

Table.5 Antibacterial activity of Adhatodha vasica E3 extract

\begin{tabular}{|l|l|l|l|}
\hline S.No & \multirow{2}{*}{ Microbial Culture } & Concentration of the E3 extract \\
\cline { 3 - 4 } & & $0.5 \mathrm{mg} / 100 \mu \mathrm{l}$ & $1 \mathrm{mg} / 100 \mu \mathrm{l}$ \\
\hline 1. & S1 & 9 & 11 \\
\hline 2. & S2 & 14 & 16 \\
\hline 3. & S3 & 9 & 12 \\
\hline 4. & S4 & 8 & 9 \\
\hline 5. & S5 & 11 & 14 \\
\hline
\end{tabular}


Table.6 Phytochemical analysis of Adhatodha vasica leaves extracts

\begin{tabular}{|l|l|l|l|l|}
\hline & \multicolumn{3}{|l|}{ Leaves } \\
\hline S. No. & Phytochemicals & Ethanolic extract & Methanolic extract & Aqueous extract \\
\hline $\mathbf{1}$ & Glycosides & $-\mathrm{ve}$ & $-\mathrm{ve}$ & $-\mathrm{ve}$ \\
\hline $\mathbf{2}$ & Carbohydrates & $+\mathrm{ve}$ & $+\mathrm{ve}$ & $+\mathrm{ve}$ \\
\hline $\mathbf{3}$ & Flavonoids & $+\mathrm{ve}$ & $+\mathrm{ve}$ & $+\mathrm{ve}$ \\
\hline $\mathbf{4}$ & Saponins & $+\mathrm{ve}$ & $+\mathrm{ve}$ & $+\mathrm{ve}$ \\
\hline $\mathbf{5}$ & Tannins & $+\mathrm{ve}$ & $+\mathrm{ve}$ & $+\mathrm{ve}$ \\
\hline $\mathbf{6}$ & Alkaloids & $+\mathrm{ve}$ & $+\mathrm{ve}$ & $+\mathrm{ve}$ \\
\hline
\end{tabular}

Table.7 Quantitative analysis of Adhatodha vasica different extracts

\begin{tabular}{|l|l|l|l|}
\hline Extracts & \multicolumn{3}{|c|}{ Phytochemicals } \\
\hline & Phenol & Saponins & Flavonoids \\
\hline E1 $(\boldsymbol{\mu g} / \mathbf{m l})$ & $\mathbf{0 . 0 2 3}$ & 0.052 & $\mathbf{0 . 1 0 6}$ \\
\hline E2 $(\boldsymbol{\mu} \mathbf{g} / \mathbf{m l})$ & $\mathbf{0 . 0 3 7}$ & 0.019 & $\mathbf{0 . 0 1 9}$ \\
\hline E3 $(\boldsymbol{\mu g} / \mathbf{m l})$ & 0.011 & $\mathbf{0 . 0 9 4}$ & 0.009 \\
\hline
\end{tabular}

Table.8 The MIC, MBC and MIC Index values of ethyl acetate extract

Against different pathogens

\begin{tabular}{|l|l|l|l|l|l|l|l|}
\hline Organism & $\begin{array}{l}\text { Range } \\
(\mathbf{m g} / \mathbf{m l})\end{array}$ & $\begin{array}{l}\text { MIC } \\
\text { (control) } \\
(\mathbf{m g} / \mathbf{m l}\end{array}$ & $\begin{array}{l}\text { MBC } \\
\text { (control) } \\
(\mathbf{m g} / \mathbf{m l})\end{array}$ & $\begin{array}{l}\text { MIC } \\
\text { (extract) } \\
(\mathbf{m g} / \mathbf{m l}\end{array}$ & $\begin{array}{l}\text { MBC } \\
\text { (extract) } \\
(\mathbf{m g} / \mathbf{m l})\end{array}$ & $\begin{array}{l}\text { MIC Index } \\
\text { (control) }\end{array}$ & $\begin{array}{l}\text { MIC Index } \\
\text { (extract) }\end{array}$ \\
\hline S1 & $0.5-0.0156$ & 0.0156 & 0.0312 & 0.125 & 0.25 & 2 & 2 \\
\hline S2 & $0.5-0.0156$ & 0.0156 & 0.0312 & 0.125 & 0.25 & 2 & 2 \\
\hline S3 & $0.5-0.0156$ & 0.0156 & 0.0312 & 0.125 & 0.25 & 2 & 2 \\
\hline S4 & $0.5-0.0156$ & 0.0156 & 0.0312 & 0.0625 & 0.125 & 2 & 2 \\
\hline S5 & $0.5-0.0156$ & 0.0156 & 0.0312 & 0.125 & 0.25 & 2 & 2 \\
\hline
\end{tabular}

Table.9 The MIC, MBC and MIC Index values of methanol extract against different pathogens

\begin{tabular}{|l|l|l|l|l|l|l|l|}
\hline Organism & $\begin{array}{l}\text { Range } \\
(\mathbf{m g} / \mathbf{m l})\end{array}$ & $\begin{array}{l}\text { MIC } \\
\text { (control) } \\
(\mathbf{m g} / \mathbf{m l}\end{array}$ & $\begin{array}{l}\text { MBC } \\
\text { (control) } \\
(\mathbf{m g} / \mathbf{m l})\end{array}$ & $\begin{array}{l}\text { MIC } \\
\text { (extract) } \\
(\mathbf{m g} / \mathbf{m l}\end{array}$ & $\begin{array}{l}\text { MBC } \\
\text { (extract) } \\
(\mathbf{m g} / \mathbf{m l})\end{array}$ & $\begin{array}{l}\text { MIC Index } \\
\text { (control) }\end{array}$ & $\begin{array}{l}\text { MIC Index } \\
\text { (extract) }\end{array}$ \\
\hline S1 & $0.5-0.0156$ & 0.0156 & 0.0312 & 0.125 & 0.25 & 2 & 2 \\
\hline S2 & $0.5-0.0156$ & 0.0156 & 0.0312 & 0.25 & 0.5 & 2 & 2 \\
\hline S3 & $0.5-0.0156$ & 0.0156 & 0.0312 & 0.25 & 0.5 & 2 & 2 \\
\hline S4 & $0.5-0.0156$ & 0.0156 & 0.0312 & 0.25 & 0.5 & 2 & 2 \\
\hline S5 & $0.5-0.0156$ & 0.0156 & 0.0312 & 0.125 & 0.25 & 2 & 2 \\
\hline
\end{tabular}

Table.10 The MIC, MBC and MIC Index values of aquous extract against different pathogens

\begin{tabular}{|l|l|l|l|l|l|l|l|}
\hline Organism & $\begin{array}{l}\text { Range } \\
(\mathbf{m g} / \mathbf{m l})\end{array}$ & $\begin{array}{l}\text { MIC } \\
\text { (control) } \\
(\mathbf{m g} / \mathbf{m l}\end{array}$ & $\begin{array}{l}\text { MBC } \\
\text { (control) } \\
(\mathbf{m g} / \mathbf{m l})\end{array}$ & $\begin{array}{l}\text { MIC } \\
\text { (extract) } \\
(\mathbf{m g} / \mathbf{m l}\end{array}$ & $\begin{array}{l}\text { MBC } \\
\text { (extract) } \\
\text { (mg/ml) }\end{array}$ & $\begin{array}{l}\text { MIC Index } \\
\text { (control) }\end{array}$ & $\begin{array}{l}\text { MIC Index } \\
\text { (extract) }\end{array}$ \\
\hline S1 & $0.5-0.0156$ & 0.0156 & 0.0312 & 0.25 & 0.5 & 2 & 2 \\
\hline S2 & $0.5-0.0156$ & 0.0156 & 0.0312 & 0.25 & 0.5 & 2 & 2 \\
\hline S3 & $0.5-0.0156$ & 0.0156 & 0.0312 & 0.25 & 0.5 & 2 & 2 \\
\hline S4 & $0.5-0.0156$ & 0.0156 & 0.0312 & 0.25 & 0.5 & 2 & 2 \\
\hline S5 & $0.5-0.0156$ & 0.0156 & 0.0312 & 0.25 & 0.5 & 2 & 2 \\
\hline
\end{tabular}


Fig.1 The antibacterial activity of E1 extract of $A$. vasica against bacterial culture

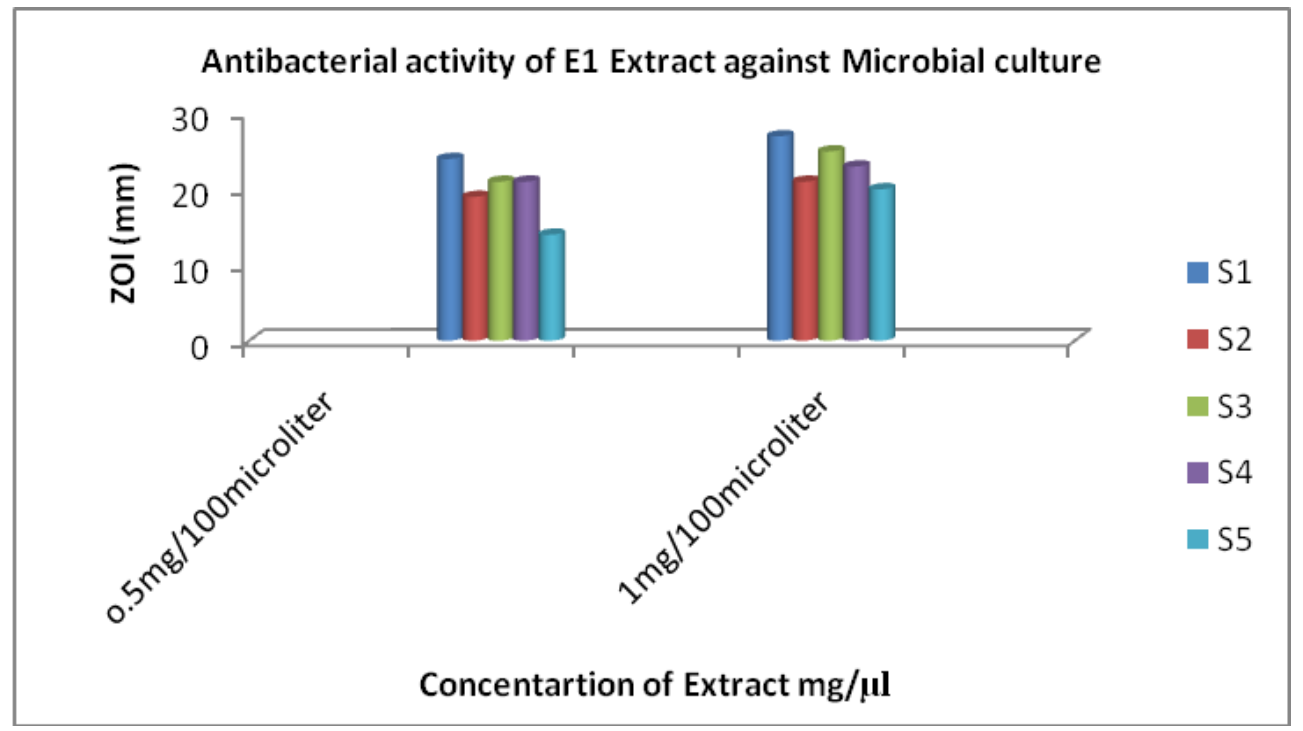

Fig.2 The presence of different phytochemicals in various extracts of $A$. vasica

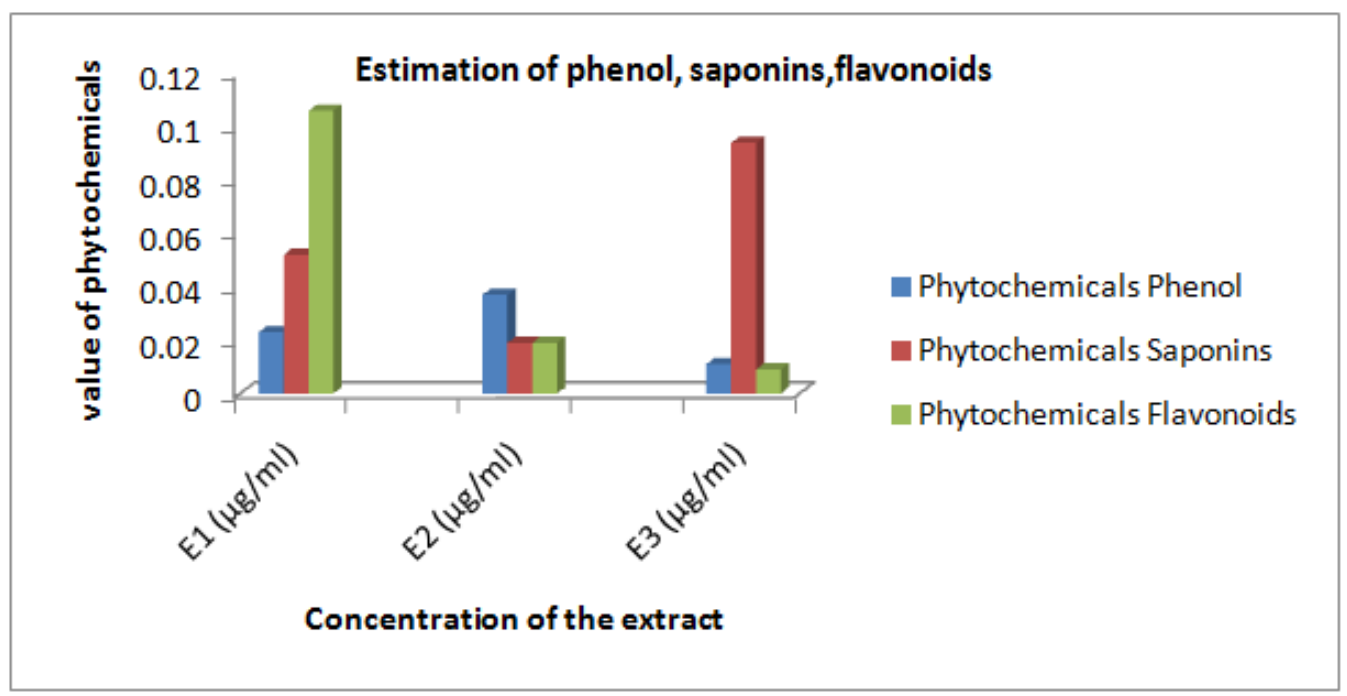

Plant material and extraction
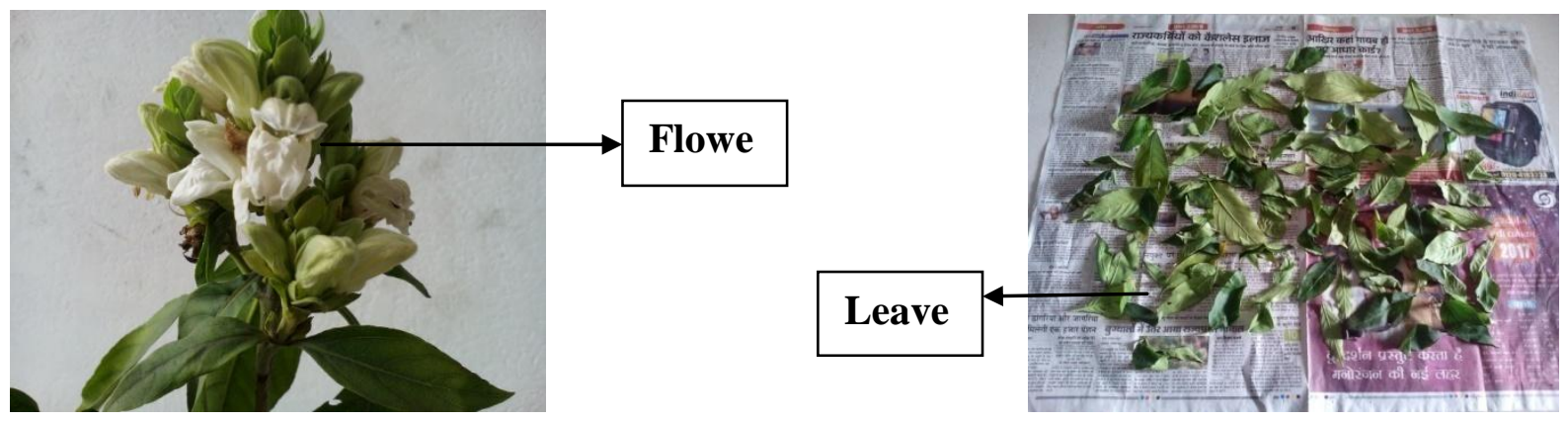


\section{MIC (Minimum Inhibitory Concentration)}

MIC is the concentration of the extract at which there is maximum inhibitory activity against microorganisms. The extracts which showed maximum inhibition on microorganisms were subjected to minimum inhibitory concentration (MIC) assay by twofold serial dilution method (2:2) (25:26). Lowest MIC value for E1 extract was $0.625 \mathrm{mg} / \mathrm{ml}$ for $S$. aureus. E2 extract showed lowest MIC concentration for $E$. coli was $0.125 \mathrm{mg} / \mathrm{ml}$ and the E3 extract showed lowest concentration of MIC for E. coli, Bacillus, Pseudomonas and S. typhi i.e. $0.125 \mathrm{mg} / \mathrm{ml}$. Elgal et al., (2017) in their study done on $A$. vasica, showed that $E$. coli and $S$. aureus were highly susceptible against the ethanolic extract of the plant having MIC concentration of $3.125 \mathrm{mg} / \mathrm{ml}$ followed by $\mathrm{S} 3$ $(\mathrm{MIC}=12.5 \mathrm{mg} / \mathrm{ml})$. While in our study the lowest MIC concentration was recorded against E1 extract for $S$. aureus.

\section{Phytochemical screening}

The E1, E2 and E3 extracts obtained from the leaves of $A$. vasica were found to be strongly active against the selected human microbes. Microbes showed four type of bactericidal effects: 1. They inhibit cell wall synthesis 2 . They stop microbial protein and nucleic acid synthesis 3 . They disrupt microbial membrane structure and function 4. They block metabolic pathways through inhibition of key enzymes (Sawhney et al., 2011). These pathogens cause various types of diseases in humans. In E1 extract Flavonoids content was found to be highest then saponins then phenolic. In E2 extract phenolic content was found to be highest then Flavonoids then saponins. In E3 extract saponins content was found to be highest then phenolic then Flavonoids of A. vasica. Presence of alkaloids, flavonoids, triterpenoids, tannins and glycosides was also confirmed by Ramachandran et al, 2013.
In our study we have focused on searching the alternative means of therapy as herbal drug formulations for bacterial infections caused by Gram positive and Gram negative bacteria in humans. The phytochemicals present in herbal drugs possess the potentiality to cure various bacterial infections and have negligible or no side effects. Various extracts of leaves of Adhatoda vasica has exhibited effective antimicrobial activity against bacterial pathogens along with the significant phytochemicals that can further be explored to obtain and use its formulations as a cure for various ailments.

\section{Acknowledgment}

The authors are thankful to R\&D of Division of Life Science, Shri Guru Ram Rai Institute of Technology and Sciences, Dehradun, India for conducting the antimicrobial and phytochemical studies. We declare that we have no conflict of interest.

\section{References}

Chauhan, Neha, Singh, Dolly, Painuli, R.M. 2012. Screening of bioprotechtive properties and phytochemical analysis of various extracts of Eclipta Alba whole plant. International Journal of Pharmacy and Pharmaceutical science, Vol 4, issue2, (553-560).

Drummond AJ and RD Waigh. The development of microbial methods for phytochemical screening. Recent Res. Devel. Phytochem 2000; 4: 143-152)

Evaluation of Bactericidal and Anticancer Properties of Fruits of piper longum, S. S. SAWHNEY*, International Journal of Pharmacy and Pharmaceutical Sciences 2011

Florey HW, Chain E and Florey ME. The Antibiotic. Vol I. New York: Oxford University $\quad$ Press; 1989. 
https://en.m.wikipedia.org $>$ wiki $>$ medici nal plants, https://nhp.gov.in>introduction and importance of medical plants and herbs

Kanthale P R and Panchal V H. Pharmacognostic study of Adhatodha vasica nees, Bioscience Discovery, 6(1): 49-53, Jan - 2015

Mohd. Sayeed Akhter et al., 2014. Asian pac J, Trop Dis., 4(suppl3):S911-S919

Mohd. Sayeed Akhter et at., 2014. Asian pac J, Trop Dis., 4(suppl3):S911-S919

National Committee for Clinical Laboratory Standards (1998). Performance Standards for antimicrobial susceptibility testing- eighth informational supplement: Approved Standard M100 S8. NCCLS 1998, Wayne, P.A.

Pharmacognostic study of Adhatodha vasica nees, Kanthale P R and Panchal V H Bioscience Discovery, 6(1): 49-53, Jan $-2015$

Sawhney S.S., Painuli R.M, Chauhan, N. Evaluation of Bactericidal and
Anticancer Properties of Fruits of piper longum, International Journal of Pharmacy and Pharmaceutical Sciences 2011; Vol 3 suppl 5 282-287

Sharly Elgal N, Jasmine. R. Identification of the compounds of Adhatoda vasica by gas chromatography-mass spectrometry analysis and probing: the mode of action of the compounds by in silico study, vol 10, issue 4, 2017

Sharma A, Bajpai VK, BaekKH., 2013.Determination of antibacterial mode of action of Allium sativum essential oil against food borne pathogens using membrane permeability and surface characteristics parameters. J Food Safety; 33(2): 197208.

Yarapa Lakshmikantha Ramachandra, Chavaan Ashajyothi Satwadi Padmalatha, Supriya Kapil Shetty Thanekar, Shirur Shruthi. 2013. Antibacterial activity of leaf extract of Adhatodha vasica. Int. J. Biomed. Pharm. Sci., 7(1), 45-47.

\section{How to cite this article:}

Ekta Chaudhary, Renu Chauhan and Neha Chauhan. 2017. Assessment of Bactericidal and Phytochemical Properties of Adhatoda vasica Various Extracts against Gram Positive and Gram Negative Bacteria. Int.J.Curr.Microbiol.App.Sci. 6(7): 2660-2669. doi: https://doi.org/10.20546/ijcmas.2017.607.375 